\title{
Comparison of GOME-2/Metop-A ozone profiles with GOMOS, OSIRIS and MLS measurements
}

\author{
A. Kauppi ${ }^{1, *}$, O. N. E. Tuinder ${ }^{2}$, S. Tukiainen ${ }^{1}$, V. Sofieva ${ }^{1}$, and J. Tamminen ${ }^{1}$ \\ ${ }^{1}$ Finnish Meteorological Institute, Earth Observation Unit, Helsinki, Finland \\ ${ }^{2}$ Royal Netherlands Meteorological Institute, De Bilt, the Netherlands \\ *formerly Määttä
}

Correspondence to: A. Kauppi (anu.kauppi@fmi.fi)

Received: 30 April 2015 - Published in Atmos. Meas. Tech. Discuss.: 23 July 2015

Revised: 22 December 2015 - Accepted: 12 January 2016 - Published: 27 January 2016

\begin{abstract}
This paper presents a comparison of vertical ozone profiles retrieved by the Ozone ProfilE Retrieval Algorithm (OPERA) (versions 1.14-1.24) from the Global Ozone Monitoring Experiment-2 (GOME-2) measurements on board the Meteorological operational Metop-A satellite with spaceborne high-vertical-resolution ozone profiles by Global Ozone Monitoring by Occultation of Stars (GOMOS), Optical Spectrograph and Infrared Imager System (OSIRIS) and Microwave Limb Sounder (MLS). The comparison, with global coverage, focuses on the stratosphere and the lower mesosphere and covers the period from March 2008 until the end of 2011.

The comparison shows an agreement of GOME-2 ozone profiles with those of GOMOS, OSIRIS and MLS within $\pm 15 \%$ in the altitude range from $15 \mathrm{~km}$ up to $\sim 35-40 \mathrm{~km}$ depending on latitude. The GOME-2 bias with respect to the reference instruments depends on season, with the strongest dependence observed at high latitudes. The GOME-2 ozone profiles retrieved from non-degradation corrected radiances have a tendency to a systematic negative bias with respect to the reference data above $\sim 30 \mathrm{~km}$. We have studied the influence of solar zenith angle and the effect of instrumental degradation correction. In addition, we have studied GOME-2 performance in Arctic ozone depletion case and demonstrated that GOME-2 data provide valuable information about ozone profiles.
\end{abstract}

\section{Introduction}

Changes in the atmospheric ozone distribution originating from natural and anthropogenic sources have an effect on the Earth's climate. These changes are altitude dependent, thus requiring continuous monitoring of the vertical distribution of ozone in the atmosphere. Ozone depletion events in the Antarctic and occasionally also in the Arctic region, as well as long-term changes in the midlatitude ozone, can be monitored by satellites that provide vertical ozone profiles. These satellite-based vertical ozone profiles have almost global coverage and can be applied for various applications and research areas from local phenomena to global evolution. Ozone profiles have been retrieved from various spaceborne instruments with different sensor types and measurement techniques since the 1970s (Hassler et al., 2014).

This paper discusses the quality of the operational ozone profiles derived from the nadir-viewing Global Ozone Monitoring Experiment-2 (GOME-2) aboard the first of a series of polar orbiting Meteorological operational (Metop) satellites Metop-A. The GOME-2 instrument (Callies et al., 2000; Munro et al., 2015) is a successor to Global Ozone Monitoring Experiment (GOME) (launched 1995). At present, there are two GOME-2 instruments flying: one on MetopA (launched 2006) and one on Metop-B (launched 2012). The third GOME-2 instrument will be launched on Metop-C (planned 2017).

The global performance of the optimal estimation-based Ozone ProfilE Retrieval Algorithm (OPERA) using measurements from GOME on board the European Space Agency's (ESA) second Earth Remote Sensing satellite (ERS-2) was studied by Mijling et al. (2010), focusing on the convergence 
behaviour of the algorithm. The impact of the first guess on the retrieved profiles as well as the choice of the ozone climatologies and ozone cross-sections were also analyzed. After the further development of OPERA, van Peet et al. (2014) have shown that the algorithm can also be applied to other nadir instruments measuring in UV-VIS range such as OMI and SCIAMACHY.

A comprehensive validation of GOME-2/Metop-A ozone profiles has been done within the framework of the EUMETSAT's Ozone Monitoring and Atmospheric Composition Satellite Application Facility (O3M SAF) project using balloon ozone sondes, lidars and microwave radiometers. The validation with the balloon and ground-based instruments covers the altitude range from the Earth's surface up to about $60 \mathrm{~km}$. The overall outcome is that, in general, the relative difference meets the operationally required target value of $30 \%$ in the troposphere at most of the reference stations. In the stratosphere the $15 \%$ target value is met below $37 \mathrm{~km}$, above which the differences increase and the GOME-2 ozone values are systematically lower compared to the ground-based instruments. The increasing negative bias in the GOME- 2 ozone profiles above $37 \mathrm{~km}$ at all the reference stations was noticed to start after November 2008. In general, the validation with ozonesondes shows better agreement at midlatitude stations than at higher latitudes and the tropical region. The detailed validation report (Kins and Delcloo, 2012) can be found at http://o3msaf.fmi.fi.

In this paper, the quality of the ozone profiles retrieved by OPERA using GOME-2/Metop-A measurements is assessed by comparison with profiles retrieved from limbviewing satellite instruments: Global Ozone Monitoring by Occultation of Stars (GOMOS), Optical Spectrograph and Infrared Imager System (OSIRIS) and Microwave Limb Sounder (MLS). The limb-viewing instruments have a significantly better vertical resolution than nadir-looking instruments, which allows probing the uncertainties related to the coarse vertical resolution of GOME-2. The selected limbviewing instruments practically do not use a priori information in the inversion. They provide ozone profiles with very high accuracy and have a small bias with respect to the ground-based measurements (e.g. van Gijsel et al., 2010). The altitude region for the comparison is between 15 and $60 \mathrm{~km}$ and the comparison period covers almost 4 full years of collocated data from March 2008 to December 2011.

The paper is organized as follows. The characteristics of the ozone profile data involved in the comparison are presented in Sects. 2 and 3. The methodology for the comparison of ozone profiles is presented in Sect. 4. Finally, the comparison results are presented and discussed in Sect. 5, and conclusions are provided in Sect. 6.

\section{GOME-2 ozone profiles}

Metop-A was launched on 19 October 2006 into a Sunsynchronous polar orbit at an altitude of about $840 \mathrm{~km}$ and is the first satellite in EUMETSAT's Metop series. GOME2 aboard Metop-A is a nadir-viewing scanning spectrometer using four channels in the ultraviolet (UV) and visible (VIS) range between 240 and $790 \mathrm{~nm}$ with a spectral resolution of $0.2-0.4 \mathrm{~nm}$. The standard footprint size of the ground pixel is usually $640 \mathrm{~km} \times 40 \mathrm{~km}$ for the UV part and $80 \mathrm{~km} \times 40 \mathrm{~km}$ for the VIS part of the spectrum. The equator crossing local time is 09:30 a.m. for the descending node. The GOME-2 measurements are used to retrieve total ozone column and ozone profiles, surface UV radiation, aerosols and total columns of $\mathrm{NO}_{2}, \mathrm{SO}_{2}, \mathrm{BrO}, \mathrm{HCHO}$ and $\mathrm{H}_{2} \mathrm{O}$ as well as tropospheric subcolumns of $\mathrm{NO}_{2}$ and ozone (Hassinen et al., 2015; Munro et al., 2006).

The GOME-2 ozone profiles are retrieved using the UVVIS spectral range between 265 and $330 \mathrm{~nm}$. The retrieved profiles are available from January 2007 onwards. The ozone profiles are generated by the OPERA algorithm developed at the Royal Netherlands Meteorological Institute (KNMI). The algorithm uses an iterative approach when fitting state vector (ozone profile) to the measured radiances using an optimal estimation method (Rodgers and Connor, 2003) and the LIDORTA radiative transfer model (van Oss and Spurr, 2002). The ozone climatology by McPeters et al. (2007) is used as a priori data. The error analysis shows that the dominant errors exceeding the $5 \%$ level originate from uncertainties in the spectral calibration, ozone a priori profile, temperature profile, cloud top pressure and forward model errors (see ATBD van Oss et al., 2014, for the details).

For users there are two types of products available: a Nearreal-time Ozone Profile product consisting of $3 \mathrm{~min}$ data blocks within $3 \mathrm{~h}$ of sensing and an Offline Ozone Profile product consisting of data blocks as whole orbits within 2 weeks. Both of these products are retrieved in a coarse resolution using $640 \mathrm{~km} \times 40 \mathrm{~km}$ ground pixels and also in a high resolution using $80 \mathrm{~km} \times 40 \mathrm{~km}$ ground pixels (see the ozone profile product user manual Tuinder, 2015). The ozone profile products are produced at KNMI and available to users in NRT via the EUMETCAST system and offline via the O3M SAF archive (http://o3msaf.fmi.fi). One orbit file contains the observations from the sun-lit side of the Earth. Global coverage can be achieved in 1.5 days with about 14 orbits daily.

In this paper, we use the operational ozone profile data from the coarse resolution Level 2 Offline Ozone Profile product. Our data set covers years 2008-2011 retrieved with nine OPERA software versions 1.14-1.24. The Level 2 ozone profile product contains a priori profile, averaging kernels, full error covariance matrix, retrieval noise covariance matrix and other relevant information (van Oss et al., 2014; Tuinder, 2015). We have used the GOME-2 ozone profiles with a quality processing flag indicating successful retrieval (Tuinder, 2015). The ozone profile is given as partial columns 
in Dobson units (DU) at 40 layers between logarithmically spaced pressure levels between the surface and $0.001 \mathrm{hPa}$ (van Oss et al., 2014; Tuinder, 2015). The cloud-top pressure replaces the surface pressure level in cloudy and partially cloudy scenes.

The vertical resolution of the ozone profile retrieved using OPERA is between 7 and $15 \mathrm{~km}$ (van Peet et al., 2014; Meijer et al., 2006). Figure 1 shows averaging kernels for a one example retrieval at pixel $\left(42.7^{\circ} \mathrm{N}, 44.5^{\circ} \mathrm{W}\right)$ on $10 \mathrm{Febru}-$ ary 2010. The nominal altitude of each averaging kernel is marked by a circle (left panel). Typically, the averaging kernels are not peaked at their nominal altitudes; this suggests that other altitudes contribute information to ozone value at individual retrieval altitude. The row sums of averaging kernel matrix (in the middle panel) show the altitude ranges where the observations are sensitive to the profile. The degrees of freedom for signal (DFS) in this example pixel is 3.5 that reveals total number of independent pieces of information. The cumulative DFS (right hand panel) indicates that the retrieved ozone profile has collected information from the measurements between 8 and $50 \mathrm{~km}$.

\section{Reference spaceborne ozone profiles used in the comparison}

In this comparison study we have used reference measurements from three satellite instruments: GOMOS/Envisat, OSIRIS/Odin and MLS/Aura. These instruments have a long-term data record with ozone profiles available for a time period between 2002 and 2012 for GOMOS, from 2001 to present for OSIRIS and from 2004 to present for MLS. Table 1 gives a short summary of the data used in the comparison; a more detailed description is presented below.

\subsection{GOMOS ozone profiles}

The GOMOS instrument on board the ESA's Envisat satellite was launched in 2002 and it monitored ozone, other trace gases (such as $\mathrm{NO}_{2}, \mathrm{NO}_{3}, \mathrm{H}_{2} \mathrm{O}$ and $\mathrm{O}_{2}$ ) and aerosols until 2012 using stars as light sources (Bertaux et al., 2010). The spectral range of the spectrometers is in the ultravioletvisible wavelengths $(248-690 \mathrm{~nm})$ and in the near-infrared (755-774 and 926-954 nm).

GOMOS utilized a stellar occultation technique to measure the vertical distribution of ozone at the altitudes between 10 and $100 \mathrm{~km}$ (Kyrölä et al., 2010). The retrieval is based on the maximum likelihood method and it uses only minimally a priori information of the vertical distribution of ozone, namely smoothness that results in vertical resolution of 2-3 km (Kyrölä et al., 2010).

The accuracy of the ozone profile derived from the GOMOS retrieval depends on the star magnitude and temperature of the star (Kyrölä et al., 2010; Tamminen et al., 2010). The most accurate ozone profiles are retrieved using
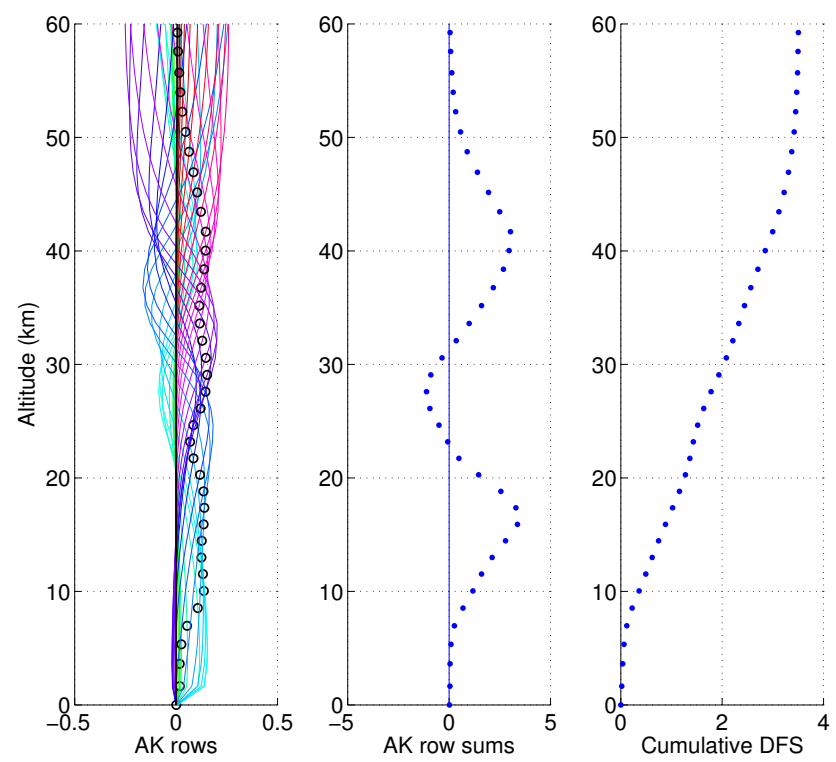

Figure 1. Averaging kernels $(\mathrm{AK})$ of GOME-2 retrieval for one pixel at $\left(42.7^{\circ} \mathrm{N}, 44.5^{\circ} \mathrm{W}\right)$ on 10 February 2010 . Rows of AK matrix (left panel), row sums of AK matrix (middle) and cumulative DFS (right panel) for the first 38 retrieval levels. The circles (left panel) represent the nominal altitudes of the averaging kernels.

the hot and bright stars. The GOMOS nighttime measurements have high precision with a retrieval error in the stratosphere around $0.5-4 \%$ and in the mesosphere around 2-10\% (Tamminen et al., 2010). The stratospheric ozone precision estimates from the GOMOS nighttime measurements have been validated by using the differential method presented by Sofieva et al. (2014). The summary of the geophysical validation of GOMOS measurements is presented in Bertaux et al. (2010).

In this comparison study, we have used nighttime (with solar zenith angle $>107^{\circ}$ ) ozone profiles from the GOMOS processor version 6 data (Table 1). We have selected only stars that are medium to bright (magnitude $M_{\mathrm{v}} \leq 2$ ) and stars that are hot (temperature $\geq 7000 \mathrm{~K}$ ). Additionally, GOMOS data were filtered for outliers and unreliable data using the recommendations of the readme document (https://earth.esa. $\mathrm{int} / \mathrm{web} / \mathrm{sppa} / \mathrm{mission}$-performance/esa-missions/envisat/ gomos/products-and-algorithms/products-information).

\subsection{OSIRIS ozone profiles}

The OSIRIS instrument on board the Swedish Odin satellite, launched in 2001, measures limb scattered solar light at the $280-810 \mathrm{~nm}$ wavelength region with around $1 \mathrm{~nm}$ spectral resolution (Llewellyn et al., 2004). OSIRIS also includes an infrared imager with three channels but in this study we only use the spectrograph data. The OSIRIS spectrograph data can be used to retrieve various trace gases such as ozone, $\mathrm{NO}_{2}$, $\mathrm{OClO}, \mathrm{BrO}$, and aerosols. OSIRIS measures the atmosphere 
Table 1. Description of ozone profile data used in this paper.

\begin{tabular}{|c|c|c|c|c|}
\hline Instrument & GOME-2 & GOMOS & OSIRIS & MLS \\
\hline Principle & nadir scatter & star occultation & limb scatter & limb thermal emission \\
\hline Local time & $\sim 09: 30$ a.m. & $\sim$ 10:00 p.m. outside polar area & $\sim 06: 00$ a.m. and 06:00 p.m. & $\sim 01: 45$ p.m. \\
\hline Algorithm version & OPERA v1.14-1.24 and v1.32 ${ }^{\mathrm{a}}$ & IPF $6.0^{b}$ & FMI v3.2 ${ }^{\mathrm{c}}$ & MLS v3.3 d \\
\hline Ozone unit & layer partial column in DU & number density & number density & volume mixing ratio \\
\hline Altitude range & $0-70 \mathrm{~km}$ & $10-100 \mathrm{~km}$ & $10-70 \mathrm{~km}$ & $261-0.02 \mathrm{hPa}$ \\
\hline Vertical levels & 41 & $100-150$ & $25-60$ & $37-47$ \\
\hline Vertical resolution & $7-15 \mathrm{~km}$, depending on altitude & $2-3 \mathrm{~km}$, depending on altitude & $2-3 \mathrm{~km}$, depending on altitude & $2.5-3 \mathrm{~km}$ \\
\hline Native vertical grid & $\begin{array}{l}\text { logarithmically spaced between surface } \\
\text { and } 0.001 \mathrm{hPa}\end{array}$ & $\begin{array}{l}\text { tangent altitudes } \\
\text { (vertical sampling < } 1.7 \mathrm{~km} \text { ) }\end{array}$ & $\sim 1-3 \mathrm{~km}$ & $\begin{array}{l}12 \text { per decade between } \\
1000 \text { and } 1 \mathrm{hPa}\end{array}$ \\
\hline $\begin{array}{l}\text { Random retrieval } \\
\text { uncertainty }\end{array}$ & $\begin{array}{l}\sim 6 \% \text { in lower troposphere } \\
<2 \% \text { in stratosphere }\end{array}$ & $0.5-4 \% \mathrm{e}^{\mathrm{e}}$ & $\begin{array}{l}0.5-3 \% \\
>3 \% \text { in lower stratosphere }\end{array}$ & $2-100 \%(261-0.1 \mathrm{hPa})^{\mathrm{d}}$ \\
\hline
\end{tabular}

${ }^{\mathrm{a}}$ van Oss et al. (2014), ${ }^{\mathrm{b}}$ Kyrölä et al. (2010), ${ }^{\mathrm{c}}$ Tukiainen et al. (2008), ${ }^{\mathrm{d}}$ Livesey et al. (2011), ${ }^{\mathrm{e}}$ Tamminen et al. (2010).

near 06:00 p.m. local solar time on the ascending node and near 06:00 a.m. local solar time on the descending node.

The OSIRIS ozone profile data used in this paper are retrieved using an onion peeling type inversion method (Tukiainen et al., 2008) developed at the Finnish Meteorological Institute (FMI). The FMI-OSIRIS Level 2 version is 3.2 and it uses the Level 1 version 55092 data. In the FMIOSIRIS ozone retrieval, around 300 wavelengths between 280 and $680 \mathrm{~nm}$ are used to produce ozone profiles between 10 and $70 \mathrm{~km}$. Generally, the FMI-OSIRIS ozone profiles agree within $\sim 5 \%$ with the GOMOS night time and MLS data (Tukiainen et al., 2008, 2015). The difference between the FMI-OSIRIS ozone and the other OSIRIS ozone product retrieved using the SaskMART algorithm (Degenstein et al., 2009 ) is typically a few percentage points in the stratosphere (Tukiainen et al., 2015).

In this comparison we only use OSIRIS morning measurements, which is convenient because GOME-2 measures in the morning too. There were some OSIRIS ozone profiles containing unrealistic ozone concentration values which were omitted from the analysis.

\subsection{MLS ozone profiles}

The MLS instrument on board the Earth Observing System (EOS) Aura satellite, launched in 2004, measures microwave thermal emission from the limb (Waters et al., 2006). The Aura satellite's equator crossing time is near 01:45 p.m. The MLS instrument observes emissions in spectral regions centred near $118,190,240,640 \mathrm{GHz}$ and $2.5 \mathrm{THz}$. The retrieved vertical profiles of trace gases include ozone, $\mathrm{BrO}$, $\mathrm{ClO}, \mathrm{CO}, \mathrm{H}_{2} \mathrm{O}, \mathrm{HCl}, \mathrm{HCN}, \mathrm{HNO}_{3}, \mathrm{~N}_{2} \mathrm{O}$ and $\mathrm{SO}_{2}$. The MLS limb-viewing measurements are processed using an optimalestimation-based retrieval method (Livesey et al., 2011).

Ozone is retrieved using the $240 \mathrm{GHz}$ retrieval. The vertical ozone profiles are reported as mixing ratios at pressure levels. The comparison in this paper includes MLS version 3.3 Level 2 ozone profiles (Livesey et al., 2011). The useful pressure range for the MLS version 3.3 ozone profiles is between 261 and $0.02 \mathrm{hPa}(\sim 10-80 \mathrm{~km})$. The MLS ozone comparison in the stratosphere with other profiles from satellite, balloon, aircraft and ground-based data resulted in an overall agreement of 5-10\% (Livesey et al., 2011).

We used MLS ozone profile data filtered using data quality metrics provided along with the profile data and as recommended in the document by Livesey et al. (2011). In addition, we only used MLS data with the SZA $<80^{\circ}$. High SZA observations often have additional uncertainties, but with MLS we can avoid these measurements because the spatiotemporal coverage is very good, anyway.

\subsection{Collocation criteria}

We selected collocated profiles with the spatiotemporal separation presented in Table 2 . They are the following: $\pm 12 \mathrm{~h}$, $\leq 400 \mathrm{~km}$ for GOMOS, $\pm 6 \mathrm{~h}, \leq 200 \mathrm{~km}$ for OSIRIS and $\pm 6 \mathrm{~h}, \leq 100 \mathrm{~km}$ for MLS. The geographic distance between GOMOS, as well as OSIRIS, and the GOME-2 ground pixel centre is calculated approximately at $30 \mathrm{~km}$ tangent point location. For MLS, the distance is calculated between the GOME-2 pixel centre and MLS geolocation. We would like to note that the geophysical distance in the atmosphere can differ from the ground distance by $20-30 \mathrm{~km}$ (Livesey et al., 2011).

For each reference instrument, the collocation criterion is a compromise of having the smallest spatiotemporal separation whilst having sufficient amount of collocations. The separation in time is dictated by the local time of the measurements. For the spatial separation with GOMOS (separation less than $400 \mathrm{~km}$ ), we used the effective horizontal resolution of the considered limb/occultation measurements (e.g. Sofieva et al., 2013). Decreasing of the allowed geographic distance or time difference reduces the number of collocated ozone profile pairs with GOMOS significantly, and also influences the spatial coverage by the collocated profiles and statistical significance of the results. More dense measurements by OSIRIS and MLS allow tighten the collocation criterion. Formally, the same collocation criterion (as for GOMOS) can be applied for all reference instruments, but this will lead to multiple collocations. In order to get statistically 
Table 2. Used coincidence criteria to define profile data pairs matched in time and space.

\begin{tabular}{lrrr}
\hline Instrument & $\begin{array}{r}\text { Time } \\
\text { difference } \\
( \pm \mathrm{h})\end{array}$ & $\begin{array}{r}\text { Geographic } \\
\text { distance } \\
(\mathrm{km})\end{array}$ & $\begin{array}{r}\text { Number of } \\
\text { collocations }\end{array}$ \\
\hline GOMOS & 12 & 400 & 514470 \\
OSIRIS & 6 & 200 & 267101 \\
MLS & 6 & 100 & 1435449 \\
\hline
\end{tabular}

independent pairs, only the closest one in time or in space should be used in the analysis. Thus, even if the collocation criteria would be formally the same, the real spatiotemporal difference will be smaller in collocations with denser samplers. Figure 2 shows latitude-time distribution of the collocated measurements. Similarity of biases (see Sect. 5) with respect to all reference instruments indicates that the selected collocation criteria are adequate for the evaluation of the GOME-2 profiles.

\section{Comparison methodology}

The retrieved GOMOS and OSIRIS vertical ozone data are ozone number density values, whereas the retrieved MLS vertical ozone data are volume mixing ratio values (Table 1). The reference ozone profiles are transformed to GOME-2 representation in DU on 40 pressure layers. For GOMOS and OSIRIS, we used pressure profiles from ECMWF (European Centre for Medium-Range Weather Forecasts), while MLS data have necessary information for such conversion.

We have smoothed the high-resolution limb profiles to the GOME-2 vertical resolution using the GOME-2 averaging kernels as (Rodgers and Connor, 2003):

$\boldsymbol{x}_{\mathrm{sref}}=\boldsymbol{x}_{\mathrm{a}}+\mathbf{A}\left(\boldsymbol{x}_{\mathrm{ref}}-\boldsymbol{x}_{\mathrm{a}}\right)$,

where $\boldsymbol{x}_{\text {sref }}$ is the resulting smoothed reference profile, $\boldsymbol{x}_{\text {ref }}$ is the actual reference profile interpolated to the GOME-2 pressure layers, $\boldsymbol{x}_{\mathrm{a}}$ is a priori profile and $\mathbf{A}$ is the averaging kernel matrix in the GOME-2 retrieval. The reference ozone profiles have significantly higher vertical resolution; therefore smoothing of GOME-2 data using averaging kernels of high-vertical resolution instruments is not effective and can be omitted (Rodgers and Connor, 2003).

We have performed the comparison between temporally and spatially coincident profiles only. The collocation criteria for each reference instrument are described in Sect. 3.4 (see also Table 2). While the calculation is done at the GOME-2 pressure layers, the results are shown in the altitude range of $15-60 \mathrm{~km}$. As the altitude layers in km vary slightly among the retrieved GOME-2 profiles, we have presented in figures the ozone layer amounts at the midpoints of the averaged altitude layers.

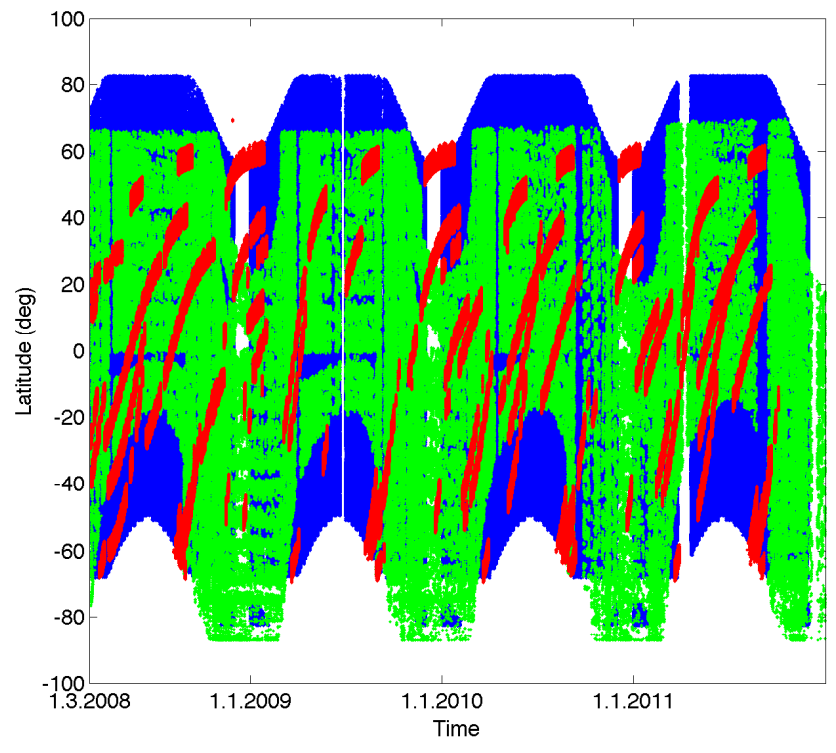

Figure 2. Latitude-time distribution of collocated data between GOME-2 and GOMOS (red), between GOME-2 and OSIRIS (green) and between GOME-2 and MLS (blue).

The relative difference (\%) used here is defined as

$\mathrm{RD}=\frac{\mathrm{GOME}-2-\mathrm{REF}}{\mathrm{REF}} \times 100 \%$,

where the ozone profiles GOME-2 and REF are in the unit of partial ozone columns in DU at 40 pressure layers.

\section{Comparison results and discussion}

\subsection{Latitude dependent difference}

The agreement between GOME-2 and the reference instruments for the whole time period is shown in Fig. 3. The ozone profiles were retrieved from GOME-2 measurements, which are not corrected for instrument degradation (see Sect. 5.5 about degradation correction).

The vertical pattern of the mean relative differences across the tropical and midlatitude regions is similar with all three instruments. The comparison shows an agreement of GOME2 ozone profiles with those of GOMOS, OSIRIS and MLS within $\pm 15 \%$ in the altitude range from $15 \mathrm{~km}$ up to $\sim 35-$ $40 \mathrm{~km}$ depending on latitude. On average, the GOME-2 ozone profiles have a positive bias from the surface up to $\sim 25 \mathrm{~km}$ and a negative bias above $\sim 30 \mathrm{~km}$ apart from the higher latitudes. The agreement between the GOME- 2 and reference ozone profiles is the best at midlatitudes. Around the equator, between $20^{\circ} \mathrm{S}$ and $20^{\circ} \mathrm{N}$, there is a higher positive bias reaching $20 \%$ at altitudes below $\sim 20 \mathrm{~km}$. The black line (upper panels) shows the mean climatological tropopause altitude. We can notice that the high positive relative bias occurs $\sim 3 \mathrm{~km}$ above the tropopause and below. 

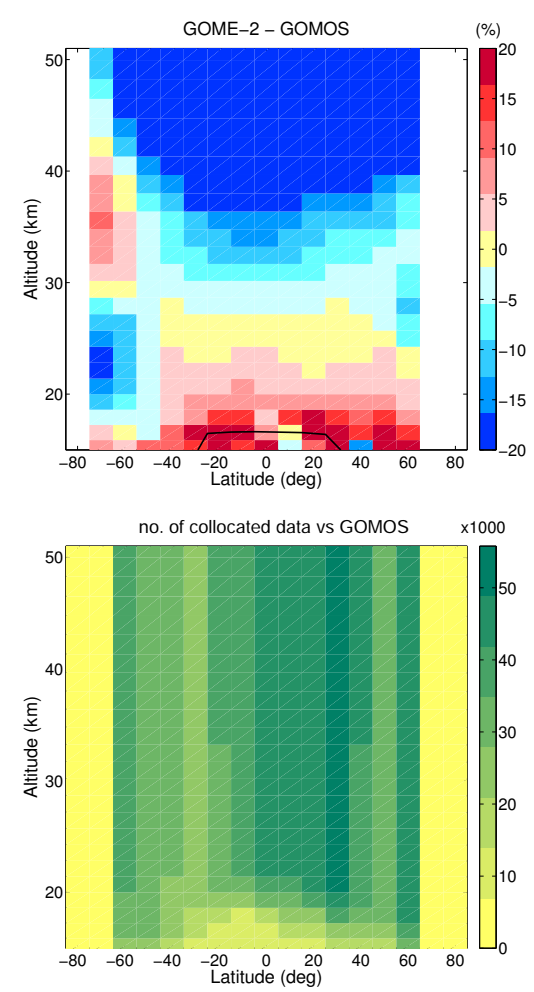
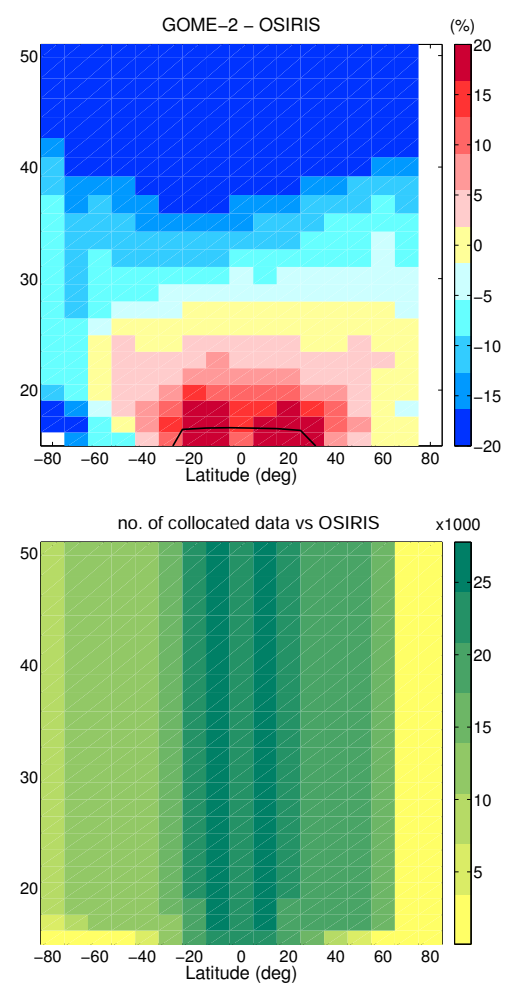
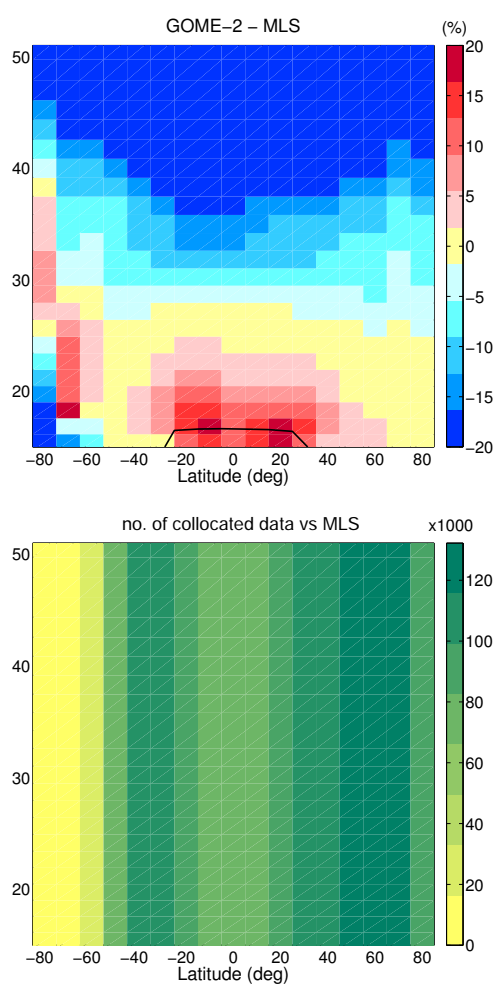

Figure 3. Top: the mean relative differences $(\%)$ at $10^{\circ}$ latitude bins of GOME-2 and the smoothed GOMOS (left), OSIRIS (middle) and MLS (right) profiles, for the full comparison period from March 2008 until December 2011. The mean profile is missing if there are less than 10 collocated profile pairs. The black line shows the mean tropopause altitude. Bottom: the number of collocated profiles with GOMOS, OSIRIS and MLS, at each altitude layer.

At southern high latitudes the averaged relative differences between GOME-2 and the reference profiles are significantly different from the midlatitudes and tropics, and they are also different from each other. In comparisons with both GOMOS and MLS, a positive bias of $\sim 10 \%$ is observed at altitudes $30-40 \mathrm{~km}$, and a negative bias $\sim 20 \%$ is observed at altitudes below $30 \mathrm{~km}$ (Fig. 3). These features at high southern latitudes are not seen in comparison with OSIRIS (Fig. 3, center). In addition, a positive bias in the zone $\sim 55-75^{\circ} \mathrm{S}$ at altitudes $18-28 \mathrm{~km}$ is observed solely in the comparisons with MLS. These differences can be explained by sampling issues related to the seasonal dependence at high latitudes as verified and discussed below in Sect. 5.2. Note that southern high latitudes have non-uniform seasonal coverage by collocated data, especially for GOMOS and OSIRIS.

\subsection{Seasonal dependence and temporal evolution of the difference}

The seasonal variation of the mean relative differences between GOME-2 ozone profiles and the averaging kernel smoothed GOMOS, OSIRIS and MLS profiles are shown in Fig. 4. As in Sect. 5.1, the GOME-2 ozone profiles are based on measurements that are not corrected for instrument degradation. In these plots, the collocated data are divided into five latitude zones. The seasons are defined as DJF (December, January, February), MAM (March, April, May), JJA (June, July, August) and SON (September, October, November). Here we consider only 2 years of data: 2010 and 2011. A period of 2 years enables a good representation of the latitudinal and seasonal dependent relative differences without excessive averaging. Note that due to large samples the detected biases are statistically significant, except a few cases of small number of collocated profiles (e.g. Fig. 4 upper left corner, $N=10$ for OSIRIS).

The seasonal variation of the bias with respect to all reference profiles is very similar, especially at the tropical and midlatitudes. At the high latitudes the divergence in comparison results may occur due to the different temporal sampling by the collocated profiles. The different air masses, being inside or outside polar vortex, can also contribute to the varying mean relative differences in the polar spring season.

In general, at tropical latitudes $\left(30^{\circ} \mathrm{S}-30^{\circ} \mathrm{N}\right)$ the seasonal variation of the mean relative difference is low. However, the negative peak in the bias just above $40 \mathrm{~km}$ is on average about $10 \%$ deeper in DJF than in the other seasons. The reason for this seasonal increase in the relative difference is not yet understood. At midlatitudes, there is a moderate seasonal vari- 

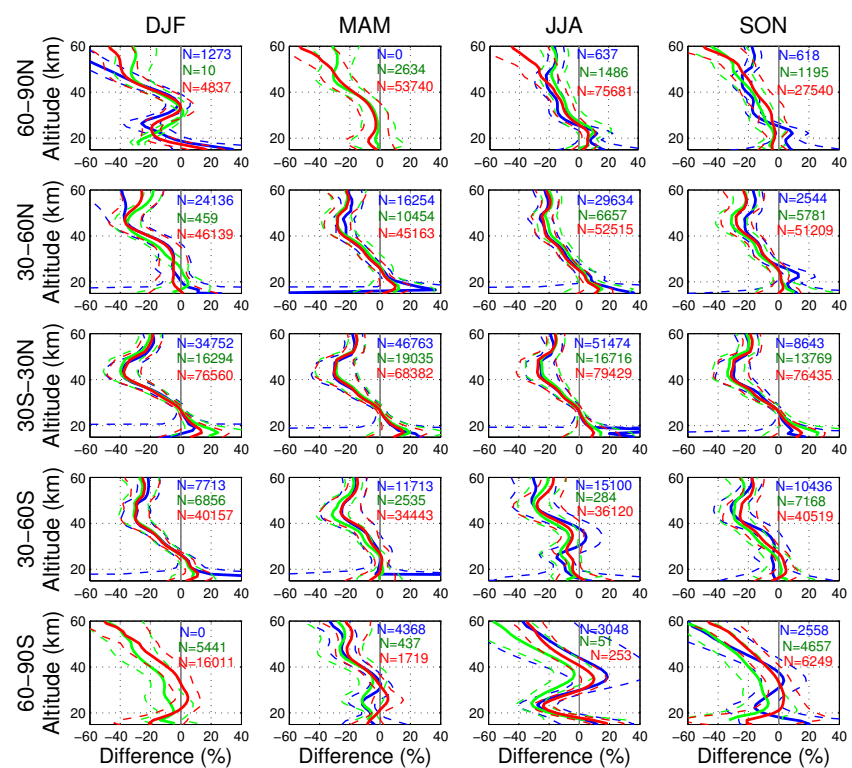

Figure 4. The mean relative differences (\%) between GOME-2 and the reference ozone profiles classified according to the latitude zones (rows) and the seasons (columns) covering years 20102011 of collocated data. The comparison results are shown against the smoothed GOMOS profiles (blue), OSIRIS profiles (green) and MLS profiles (red). The dashed lines show the $1 \sigma$ standard deviation around the mean. The number of collocated profile pairs is given in the upper right corner of each panel. The number of collocations is not always valid for the lowest altitude layers.

ation of the GOME-2 biases in the stratosphere, yet more evident at southern midlatitudes.

The seasonal dependence of the mean relative differences can be clearly seen at the high latitudes. There is a negative bias with respect to all reference data just above $20 \mathrm{~km}$ in JJA (i.e. local winter) at southern high latitudes. The same vertical structure in the relative difference is seen at the northern high latitudes in the local winter (DJF).

In SON $\left(30-90^{\circ} \mathrm{S}\right)$ and in MAM $\left(60-90^{\circ} \mathrm{S}\right)$, the shape of the bias profile is a bit different between the comparisons with the separate reference instruments. In SON $\left(30-90^{\circ} \mathrm{S}\right)$ the collocated data with GOMOS includes only September, whereas the collocated data with both OSIRIS and MLS include all three "SON" months, and the comparison results from November are very different (not shown here). In MAM $\left(60-90^{\circ} \mathrm{S}\right)$, collocated data for MLS includes March and April, whereas for GOMOS and OSIRIS only March is included (note that biases with respect to OSIRIS and GOMOS are very close to each other).

At the northern high latitudes $\left(60-90^{\circ} \mathrm{N}\right)$ the mean relative differences vs. MLS data at the upper altitude levels deviate from others in MAM and JJA. In addition, in SON $\left(60-90^{\circ} \mathrm{N}\right)$ the bias above $40 \mathrm{~km}$ is higher against OSIRIS and MLS than against GOMOS. The reason for this might be that collocations for GOMOS includes only September.

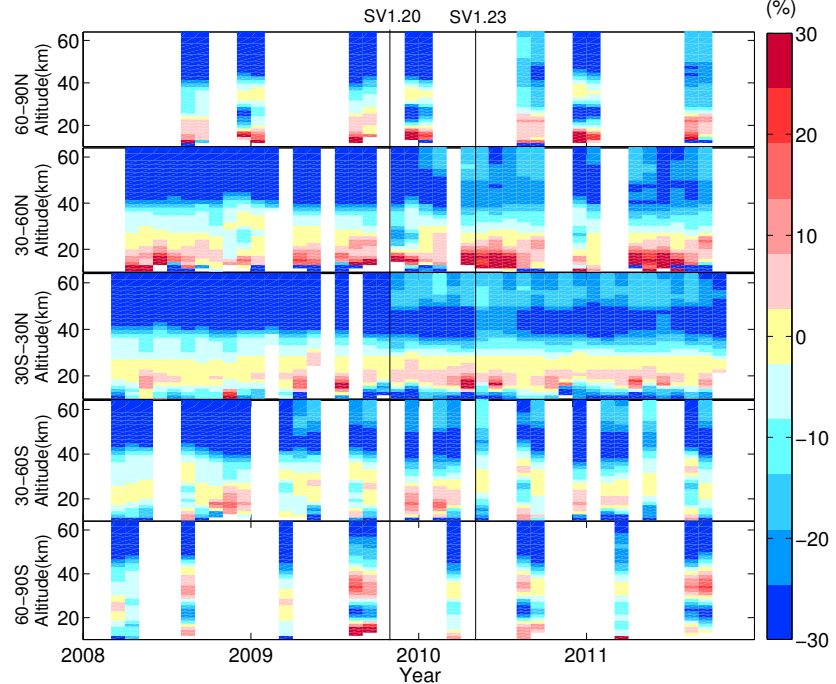

Figure 5. Monthly median relative differences between GOME-2 and smoothed GOMOS ozone profiles, in different latitude zones in the time period of 2008-2011. The monthly median is missing if there are less than 10 collocated profiles. The vertical lines indicate moments of the product software version (sv) updates 1.20 and 1.23.

At lower altitudes, the accuracy of the ozone profiles from limb-viewing instruments worsens due to lower signal-tonoise ratio thus causing a wide standard deviation around the mean relative differences (Fig. 4). When the comparison is done with the actual reference profiles, i.e. without averaging kernel smoothing, the bias is very similar than can be seen in Fig. 4 except the highest altitude layers and the tropical lowest altitude layers, and this can be expected.

Figures 5-7 show a temporal evolution of the monthly median of relative differences (\%) starting from March 2008 for each latitude zone with respect to the smoothed GOMOS, OSIRIS and MLS profiles, respectively. The GOME-2 ozone profiles in these figures are based on measurements that are not corrected for instrument degradation.

These figures confirm that the relative difference has a definite seasonal cycle at polar and midlatitudes. This can be seen especially in Figs. 6 and 7 since both OSIRIS and MLS have temporally denser data set. In the tropics, the seasonal variations in the GOME-2 biases are milder, as expected.

We can notice a change to the better agreement in the upper stratosphere and the lower mesosphere after October 2009, and even more clearly in the whole stratosphere after the end of April 2010. These changes correspond to OPERA algorithm versions 1.01 and 1.10 updates, and software version 1.20 and 1.23 updates (Tuinder, 2015).

There can be several possible reasons for the mainly systematic differences encountered with respect to the reference data. The GOME-2 ozone profiles and the reference profiles used from the GOMOS, OSIRIS and MLS instruments are collocated at different local solar times (see Table 1). It has 


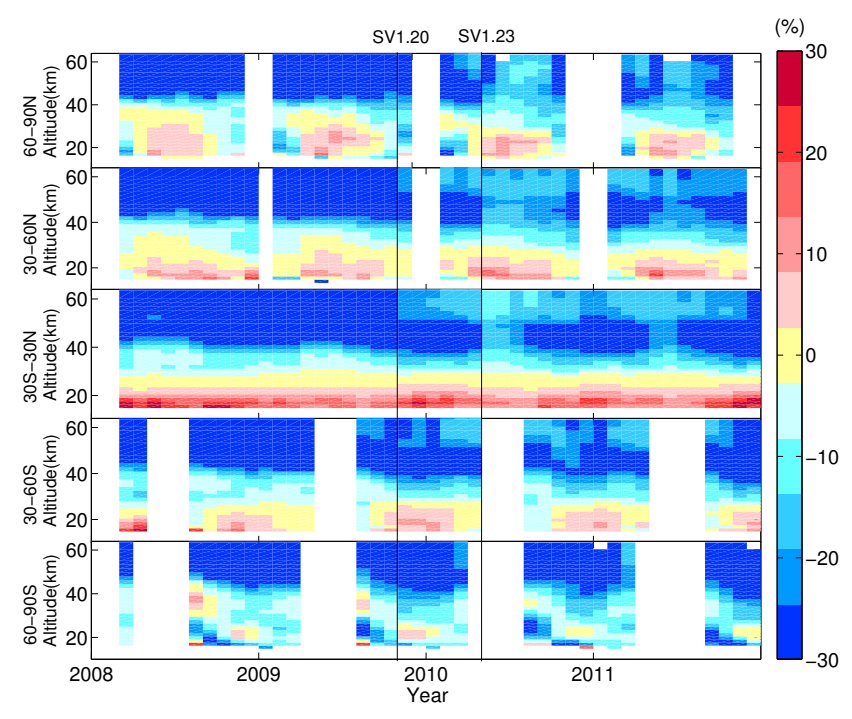

Figure 6. As Fig. 5, but for the monthly median relative differences between collocated GOME-2 and smoothed OSIRIS ozone profiles.

been shown that the natural variability of ozone is affected by the photo-chemical reactions using solar light above $40 \mathrm{~km}$ (e.g. Studer et al., 2014; Sakazaki et al., 2013). The large relative differences in the upper stratosphere with respect to GOMOS data, and to a lesser extent against OSIRIS and MLS data, could be partly caused by this diurnal effect (see Fig. 8).

The comparisons done here with occultation and limb measurements show a turning point of bias with the maximum relative differences at around $40-50 \mathrm{~km}$. In the paper by van Peet et al. (2014) it is discussed that above $2 \mathrm{hPa}$ $(\sim 45 \mathrm{~km})$ the implemented additive offset (to partially correct the influence of instrument degradation) has the largest influence on the number of pixels passing the quality control. In the validation report (Kins and Delcloo, 2012) it has been noticed that in the course of time the GOME-2/MetopA data become noisier due to the instrument degradation, mainly at higher altitudes above $40 \mathrm{~km}$. The effect of degradation correction and its influence on observed biases is discussed below in Sect. 5.5.

\subsection{Solar zenith angle dependent difference}

We have studied the dependence of GOME-2 bias on the solar zenith angle (SZA). The SZA is provided with GOME-2 ozone profile retrieval. Typically the bias increases with increasing SZA. Figures 9 and 10 show the SZA dependence of the GOME-2 bias compared to smoothed GOMOS and OSIRIS data for the altitude layers located around 23, 30, 37 and $45 \mathrm{~km}$ at the southern high latitudes $\left(60-90^{\circ} \mathrm{S}\right)$. We show here bias only for one latitude zone, $60-90^{\circ} \mathrm{S}$, since only there do exceptionally high bias values that depend on SZA occur. The results were similar for all years; thus we only show data from 2010.

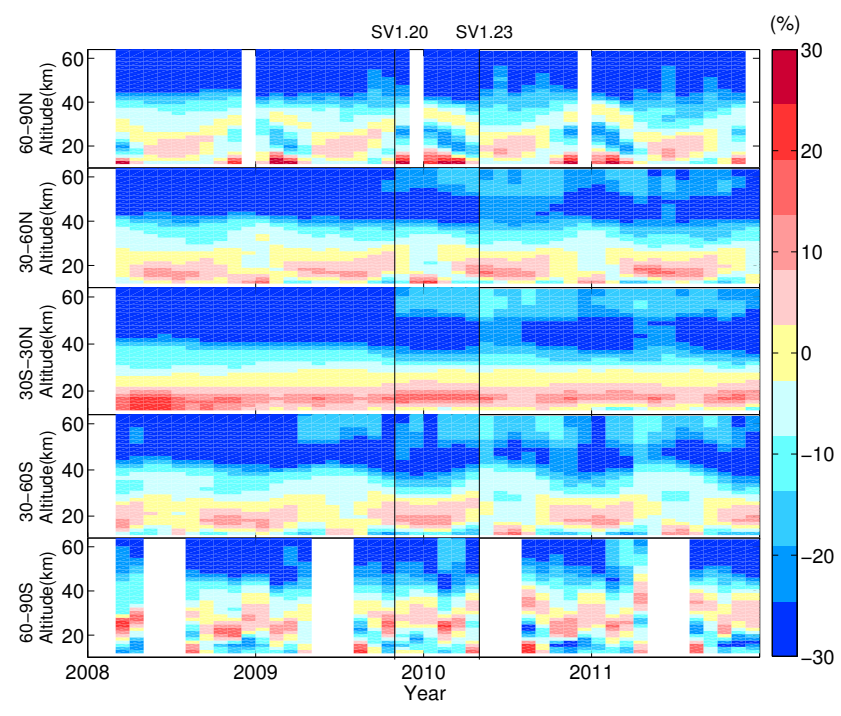

Figure 7. As Figs. 5 and 6, but for the monthly median relative differences between collocated GOME-2 and smoothed MLS ozone profiles.

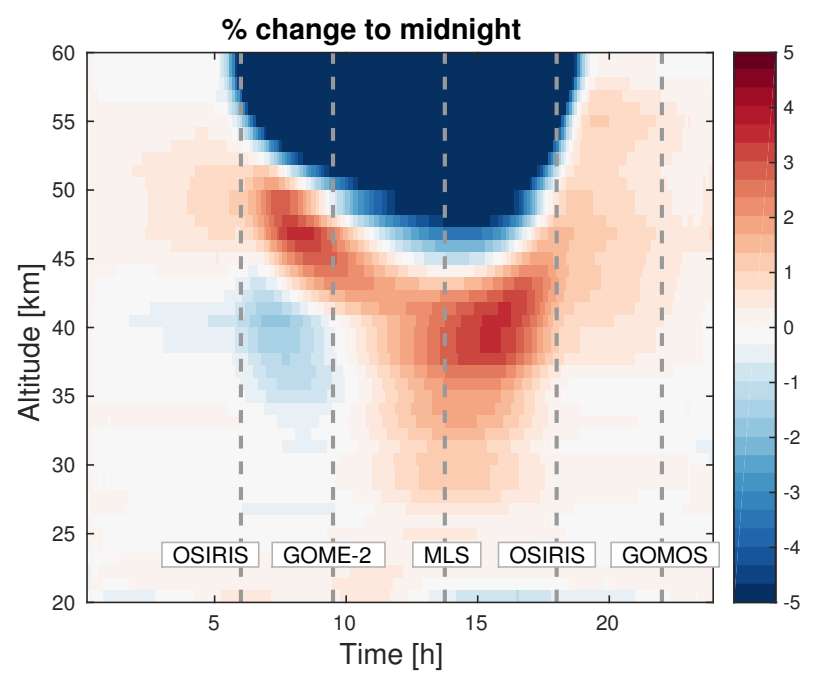

Figure 8. The diurnal variation of ozone between the latitudes 20 and $30^{\circ} \mathrm{N}$ illustrated by the Whole Atmosphere Community Climate Model (WACCM). The local solar times of OSIRIS, GOME-2, MLS and GOMOS measurements are marked with dashed vertical lines.

At the southern high latitudes the negative bias increases with increasing SZA around $23 \mathrm{~km}$ altitude. This is also observed at northern high latitudes, $60-90^{\circ} \mathrm{N}$ (not shown here). A similar dependence on SZA at tropical and midlatitude regions was registered around $45 \mathrm{~km}$ (not shown here). On the contrary, at the southern midlatitudes around $37 \mathrm{~km}$ there is a tendency for the (negative) bias to get smaller; i.e. there is better agreement when the SZA increases (not shown here).

In Figs. 9 and 10 exceptionally large positive relative differences with respect to both GOMOS and OSIRIS data 

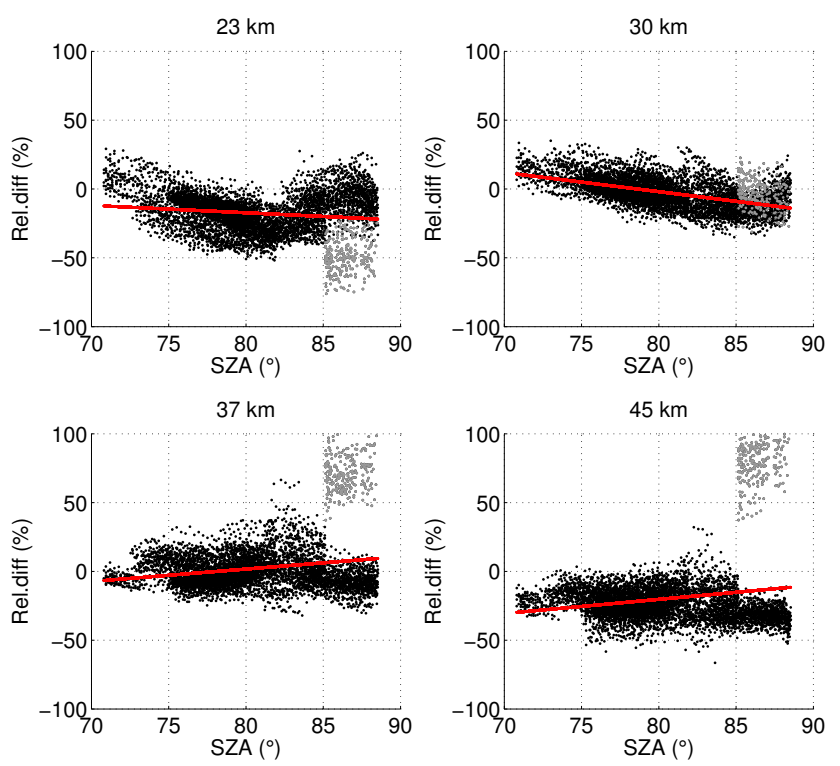

Figure 9. The relative differences $(\%)$ with respect to smoothed GOMOS profiles as a function of GOME-2 SZA, at four altitude layers around $23 \mathrm{~km}$ (upper left), $30 \mathrm{~km}$ (upper right), $37 \mathrm{~km}$ (bottom left) and $45 \mathrm{~km}$ (bottom right). The profiles are from the southern high latitudes $\left(60-90^{\circ} \mathrm{S}\right)$ covering 1 year (2010) of comparison data. The grey dots represent the same GOME-2 pixels at all the altitude layers. They indicate high disagreement values (except at altitude layer around $30 \mathrm{~km}$ ).

appear above $\sim 30 \mathrm{~km}$ when $\mathrm{SZA}>85^{\circ}$ and at the same time large negative differences occur around $23 \mathrm{~km}$. We have marked these pixels by grey and they represent the same pixels at all the altitude layers. We can notice that at $\sim 30 \mathrm{~km}$ (top right panel in Fig. 9) these pixels do not have divergent relative difference values. In addition, the very high positive relative differences with respect to OSIRIS profiles are encountered when SZA is between 68 and $80^{\circ}$ (marked with grey dots in Fig. 10). This happens only in the southernmost latitude levels around $87^{\circ} \mathrm{S}$ during the southern polar spring and summer months. The reason for these exceptionally high bias values is not known at the moment; this feature will be investigated in the future studies. The collocated pixels with GOMOS data have the southernmost latitudes around $69^{\circ} \mathrm{S}$ thus these high difference values are not seen against GOMOS data (Fig. 9).

\subsection{Arctic ozone depletion 2011}

In order to demonstrate the usefulness of the GOME-2 data we considered the ozone profiles retrieved from the GOME-2 measurements during the Arctic ozone depletion in spring 2011. In the Antarctic region the ozone hole event recurs annually, but in the Arctic region severe ozone loss happens less frequently. The exceptionally reduced transport of ozone from midlatitudes into the Arctic region together with enhanced chemical ozone loss inside polar vortex caused the
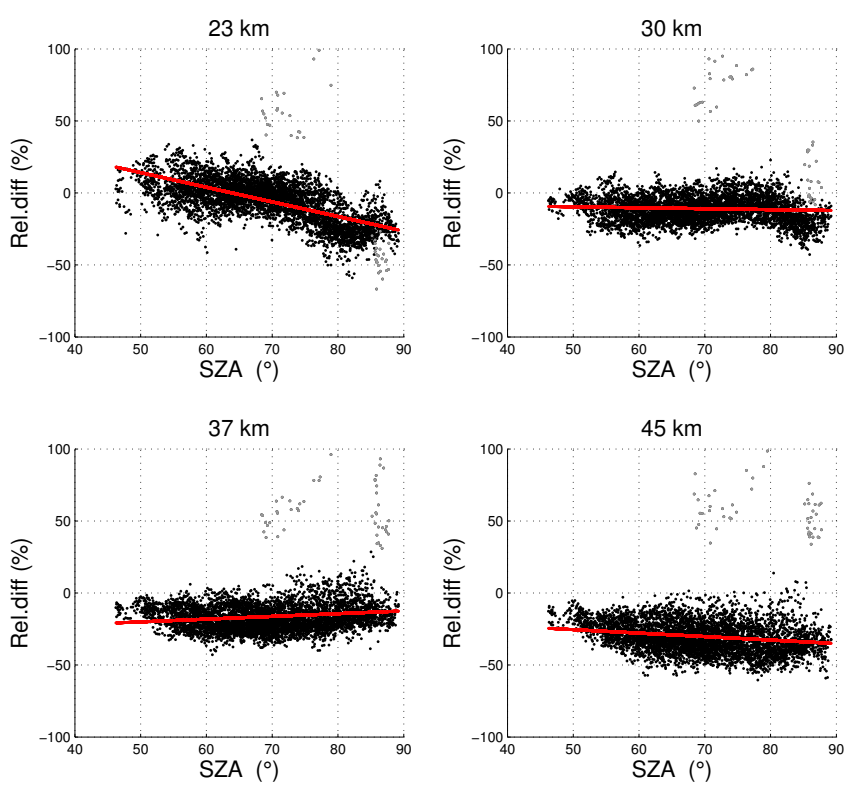

Figure 10. As Fig. 9, but against smoothed OSIRIS profiles.

anomalously low ozone concentration over the North Pole in March 2011 (Manney et al., 2011; Isaksen et al., 2012). The Arctic ozone depletion is not represented by the typical a priori profile used for this season and latitude and hereby offers a chance to verify the retrieved profiles under the challenging circumstances.

As the air masses inside the polar vortex can be very different compared to outside polar vortex atmosphere, the comparisons have been done separately for the pixels being inside and outside the polar vortex. We have done the comparison over Arctic region $\left(60-90^{\circ} \mathrm{N}\right)$ with collocated OSIRIS data and used $475 \mathrm{~K}$ potential vorticity associated with OSIRIS data to determine the collocated GOME-2 pixel to be outside or inside polar vortex area. In this special case, we require pixels to a $\mathrm{SZA} \leq 65^{\circ}$ because the disagreement with reference data increases as SZA increases at high latitudes when considering the altitude range around $20 \mathrm{~km}$ (see previous Sect. 5.3). The number of collocated profiles inside vortex is 17 and outside vortex 96 , respectively. In reality, as the division is not the same at all altitudes, some part of the profile can be inside, and the rest of the profile can be outside of the polar vortex.

Figure 11 shows the monthly averages for March 2011 of collocated ozone profiles from GOME-2 and OSIRIS measurements separately for profiles inside (left hand panel) and outside polar vortex (middle panel). The retrieved GOME-2 mean profile inside polar vortex is far away from a priori profile and is rather close to the OSIRIS profile. Outside polar vortex, all profiles are close to each other. Interestingly, in this case the OSIRIS mean profiles agree better with a priori values, especially in outside polar vortex situation. Probably, this happened by chance. 

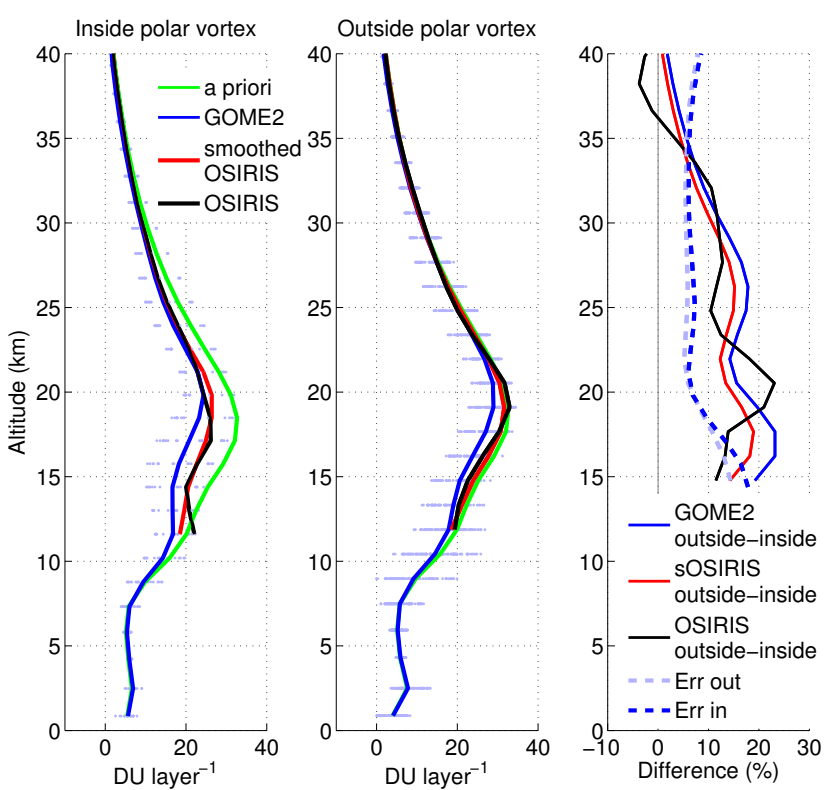

Figure 11. Monthly averages of the collocated GOME-2 (blue), OSIRIS (black), smoothed OSIRIS (red) and a priori (green) ozone profiles inside polar vortex (left panel) and outside polar vortex (middle panel) in the high northern latitudes $\left(60-90^{\circ} \mathrm{N}\right)$ in March 2011. The individual GOME-2 ozone amounts at each altitude layer are denoted by blue dots. The relative differences (\%) between outside and inside polar vortex monthly means for GOME2, OSIRIS and smoothed OSIRIS are shown in the right panel. In this same figure are plotted corresponding mean GOME-2 relative retrieval errors outside and inside polar vortex (dashed lines).

The difference between inside and outside polar vortex monthly mean values scaled by outside polar vortex monthly mean is evident as seen for GOME-2 (blue) and OSIRIS (red and black) (Fig. 11 right panel). In this figure are shown also the mean GOME-2 relative retrieval errors outside and inside polar vortex separately.

This case study shows that the GOME- 2 can observe the ozone depletion well and thus provides very useful information. We would like to note that the horizontal coverage by GOME-2 is much more dense than by limb-viewing instruments.

\subsection{Correction for instrumental degradation}

The GOME-2 vertical ozone profile algorithm depends strongly on good absolute-calibrated solar and earthshine spectra. Unfortunately, GOME-2 is affected by instrument degradation that is strongest in UV (Munro et al., 2015). This instrumental degradation increases over time, thus setting additional challenges to the algorithm to adapt to these changes. An experimental correction has been developed, which aims to rectify an initial bias and the time dependent degradation for a number of relevant wavelengths and scan angles. This degradation correction is applied to the measurement, leav-
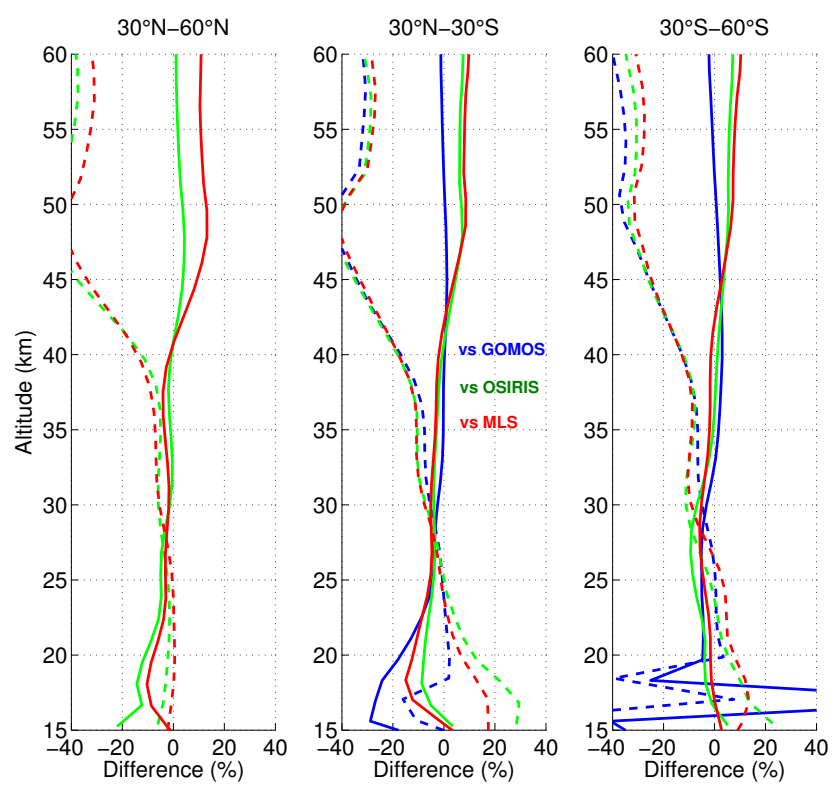

Figure 12. Monthly averages of the relative differences (\%) with respect to the collocated smoothed GOMOS (blue), OSIRIS (green) and MLS (red) ozone profiles in March 2008. The results are shown for three latitude zones separately when using the operational GOME-2 data (dashed curves) and data with the new experimental correction for instrumental degradation (solid curves).

ing all other Opera ozone profile algorithmic features intact. The data produced with the degradation correction is only used for comparisons in this section, not in the operational data shown earlier in this paper. This limited reprocessed GOME-2 data set was generated with OPERA version 1.32.

To demonstrate its potential we have done some comparisons of GOME-2 vertical ozone profiles using a newly developed experimental degradation correction with the GOMOS, OSIRIS and MLS data. The preliminary results for March 2008, shown in Fig. 12, indicate good functionality of the implemented correction. The large underestimation of ozone above $40 \mathrm{~km}$ has been turned into a smaller overestimation, rectifying the deviation considerably. The operational ozone profiles (dashed curves) used here are from the offline ozone product (OOP) with software version 1.14 in coarse resolution, whereas the degradation corrected profiles (solid curves) have been retrieved in higher resolution. Thus the number of collocated profiles in comparison is higher when using higher resolution GOME-2 data. Since the beginning of the O3M SAF, the operationally available vertical ozone profile product has been under continuous development and improvement (Tuinder, 2015). This can be seen also in timeline comparison results of the upper stratosphere, e.g. after 2010 (Figs. 5-7). 


\section{Conclusions}

We have evaluated the accuracy of the GOME-2 ozone profiles based on measurements that are not corrected for instrument degradation. This has been done on a global scale by comparing GOME-2 ozone profiles with high-vertical resolution spaceborne ozone profiles by GOMOS, OSIRIS and MLS. In this comparison study, we have used spatially and temporally coincident profiles for the time period from March 2008 to December 2011.

The bias with respect to all reference instruments is very similar; it depends on altitude, latitude and season. The overall agreement of ozone profiles from GOME-2 and other instruments is within $15 \%$ below $35-40 \mathrm{~km}$. The comparison shows that, in general, there is a negative bias in the GOME2 ozone profiles above around $30 \mathrm{~km}$. On the other hand, GOME-2 systematically overestimates ozone in the lower stratosphere at tropical and midlatitudes. At high latitudes, the bias has more clear seasonal-dependent variations. Typically the bias increases with increasing SZA.

The methodology for the GOME-2 instrumental degradation correction is in the experimental phase. The preliminary evaluation done with the limited degradation corrected data set has shown dramatic reduction of biases at upper altitudes, thus indicating good functionality of the implemented correction.

The detailed investigation considering the exceptional ozone depletion at Arctic during the spring 2011 showed that the GOME-2 ozone profiles captured the unusual ozone vertical structure in spite of an a priori ozone profile that was not representative of that situation. This indicates that GOME-2 data can provide valuable geophysical information.

Acknowledgements. The GOME-2 vertical ozone profiles are provided by EUMETSAT's Ozone Monitoring and Atmospheric Composition Satellite Application Facility (O3M SAF). The authors would like to thank the GOMOS, OSIRIS and MLS data providers for data availability. This work has been done in the context of the O3M SAF project and the Academy of Finland INQUIRE and ASTREX projects.

Edited by: P. Stammes

\section{References}

Bertaux, J. L., Kyrölä, E., Fussen, D., Hauchecorne, A., Dalaudier, F., Sofieva, V., Tamminen, J., Vanhellemont, F., Fanton d'Andon, O., Barrot, G., Mangin, A., Blanot, L., Lebrun, J. C., Pérot, K., Fehr, T., Saavedra, L., Leppelmeier, G. W., and Fraisse, R.: Global ozone monitoring by occultation of stars: an overview of GOMOS measurements on ENVISAT, Atmos. Chem. Phys., 10, 12091-12148, doi:10.5194/acp-10-12091-2010, 2010.

Callies, J., Corpaccioli, E., Eisinger, M., Hahne, A., and Lefebvre, A.: GOME-2 - Metop's second-generation sensor for operational ozone monitoring, ESA Bull.-Eur. Space., 102, 28-36, 2000.

Degenstein, D. A., Bourassa, A. E., Roth, C. Z., and Llewellyn, E. J.: Limb scatter ozone retrieval from 10 to $60 \mathrm{~km}$ using a multiplicative algebraic reconstruction technique, Atmos. Chem. Phys., 9, 6521-6529, doi:10.5194/acp-9-6521-2009, 2009.

Hassinen, S., Balis, D., Bauer, H., Begoin, M., Delcloo, A., Eleftheratos, K., Gimeno Garcia, S., Granville, J., Grossi, M., Hao, N., Hedelt, P., Hendrick, F., Hess, M., Heue, K.-P., Hovila, J., JønchSørensen, H., Kalakoski, N., Kiemle, S., Kins, L., Koukouli, M. E., Kujanpää, J., Lambert, J.-C., Lerot, C., Loyola, D., Määttä, A., Pedergnana, M., Pinardi, G., Romahn, F., van Roozendael, M., Lutz, R., De Smedt, I., Stammes, P., Steinbrecht, W., Tamminen, J., Theys, N., Tilstra, L. G., Tuinder, O. N. E., Valks, P., Zerefos, C., Zimmer, W., and Zyrichidou, I.: Overview of the O3M SAF GOME-2 operational atmospheric composition and UV radiation data products and data availability, Atmos. Meas. Tech. Discuss., 8, 6993-7056, doi:10.5194/amtd-8-6993-2015, 2015.

Hassler, B., Petropavlovskikh, I., Staehelin, J., August, T., Bhartia, P. K., Clerbaux, C., Degenstein, D., Mazière, M. De, Dinelli, B. M., Dudhia, A., Dufour, G., Frith, S. M., Froidevaux, L., GodinBeekmann, S., Granville, J., Harris, N. R. P., Hoppel, K., Hubert, D., Kasai, Y., Kurylo, M. J., Kyrölä, E., Lambert, J.-C., Levelt, P. F., McElroy, C. T., McPeters, R. D., Munro, R., Nakajima, H., Parrish, A., Raspollini, P., Remsberg, E. E., Rosenlof, K. H., Rozanov, A., Sano, T., Sasano, Y., Shiotani, M., Smit, H. G. J., Stiller, G., Tamminen, J., Tarasick, D. W., Urban, J., van der A, R. J., Veefkind, J. P., Vigouroux, C., von Clarmann, T., von Savigny, C., Walker, K. A., Weber, M., Wild, J., and Zawodny, J. M.: Past changes in the vertical distribution of ozone - Part 1: Measurement techniques, uncertainties and availability, Atmos. Meas. Tech., 7, 1395-1427, doi:10.5194/amt-7-13952014, 2014.

Isaksen, I. S. A., Zerefos, C., Wang, W.-C., Balis, D., Eleftheratos, K., Rognerud, B., Stordal, F., Berntsen, T. K., LaCasce, J. H., Søvde, O. A., Olivié, D., Orsolini, Y. J., Zyrichidou, I., Prather, M., and Tuinder, O. N. E.: Attribution of the Arctic ozone column deficit in March 2011, Geophys. Res. Lett., 39, L24810, doi:10.1029/2012GL053876, 2012.

Kins, L. and Delcloo, A.: O3M SAF Validation Report for Near-Real-Time Ozone Profile, Offline Ozone Profile, NearReal-Time High Resolution Ozone Profile and Offline High Resolution Ozone Profile products, SAF/O3M/DWD/VR/OOP/091, Ozone SAF Validation reports, O3M SAF, available at: http://o3msaf.fmi.fi/docs/vr/Validation_Report_NOP_NHP_ OOP_OHP_Feb_2012.pdf (last access: 20 July 2015), 2012.

Kyrölä, E., Tamminen, J., Sofieva, V., Bertaux, J. L., Hauchecorne, A., Dalaudier, F., Fussen, D., Vanhellemont, F., Fanton d'Andon, 
O., Barrot, G., Guirlet, M., Mangin, A., Blanot, L., Fehr, T., Saavedra de Miguel, L., and Fraisse, R.: Retrieval of atmospheric parameters from GOMOS data, Atmos. Chem. Phys., 10, 1188111903, doi:10.5194/acp-10-11881-2010, 2010.

Livesey, N. J., Read, W. G., Froidevaux, L., Lambert, A., Manney, G. L., Pumphrey, H. C., Santee, M. L., Schwartz, M. J., Wang, S., Cofeld, R. E., Cuddy, D. T., Fuller, R. A., Jarnot, R. F., Jiang, J. H., Knosp, B. W., Stek, P. C., Wagner, P. A., and Wu, D. L.: EOS MLS Version 3.3 Level 2 data quality and description document, JPL D-33509, Jet Propulsion Laboratory, Version 3.3x-1.0, available at: http://mls.jpl.nasa.gov/data/v3-3_ data_quality_document.pdf (last access: 20 July 2015), 2011.

Llewellyn, E. J., Lloyd, N. D., Degenstein, D. A., Gattinger, R. L., Petelina, S. V., Bourassa, A. E., Wiensz, J. T., Ivanov, E. V., McDade, I. C., Solheim, B. H., McConnell, J. C., Haley, C. S., von Savigny, C., Sioris, C. E., McLinden, C. A., Griffioen, E., Kaminski, J., Evans, W. F. J., Puckrin, E., Strong, K., Wehrle, V., Hum, R. H., Kendall, D. J. W., Matsushita, J., Murtagh, D. P., Brohede, S., Stegman, J., Witt, G., Barnes, G., Payne, W. F., Piché, L., Smith, K., Warshaw, G., Deslauniers, D.-L., Marchand, P., Richardson, E. H., King, R. A., Wevers, I., McCreath, W., Kyrölä, E., Oikarinen, L., Leppelmeier, G. W., Auvinen, H., Mégie, G., Hauchecorne, A., Lefèvre, F., de La Nöe, J., Ricaud, P., Frisk, U., Sjoberg, F., von Schéele, F., and Nordh, L.: The OSIRIS instrument on the Odin spacecraft, Can. J. Phys., 82, 411-422, doi:10.1139/P04-005, 2004.

Manney, G. L., Santee, M. L., Rex, M., Livesey, N. J., Pitts, M. C., Veefkind, P., Nash, E. R., Wohltmann, I., Lehmann, R., Froidevaux, L., Poole, L. R., Schoeberl, M. R., Haffner, D. P., Davies, J., Dorokhov, V., Gernandt, H., Johnson, B., Kivi, R., Kyrö, E., Larsen, N., Levelt, P. F., Makshtas, A., McElroy, C. T., Nakajima, H., Parrondo, M. C., Tarasick, D. W., von der Gathen, P., Walker, K. A., and Zinoviev, N. S.: Unprecedented Arctic ozone loss in 2011, Nature, 478, 469-475, doi:10.1038/nature10556, 2011.

McPeters, R. D., Labow, G. J., and Logan, J. A.: Ozone climatological profiles for satellite retrieval algorithms, J. Geophys. Res., 112, D05308, doi:10.1029/2005JD006823, 2007.

Meijer, Y. J., Swart, D. P. J., Baier, F., Bhartia, P. K., Bodeker, G. E., Casadio, S., Chance, K., Del Frate, F., Erbertseder, T., Felder, M. D., Flynn, L. E., Godin-Beekmann, S., Hansen, G., Hasekamp, O. P., Kaifel, A., Kelder, H. M., Kerridge, B. J., Lambert, J.-C., Landgraf, J., Latter, B., Liu, X., McDermid, I. S., Pachepsky, Y., Rozanov, V., Siddans, R., Tellmann, S., van $\operatorname{der}$ A, R. J., van Oss, R. F., Weber, M., and Zehner, C.: Evaluation of Global Ozone Monitoring Experiment (GOME) ozone profiles from nine different algorithms, J. Geophys. Res.-Atmos., 111, 21306, doi:10.1029/2005JD006778, 2006.

Mijling, B., Tuinder, O. N. E., van Oss, R. F., and van der A, R. J.: Improving ozone profile retrieval from spaceborne UV backscatter spectrometers using convergence behaviour diagnostics, Atmos. Meas. Tech., 3, 1555-1568, doi:10.5194/amt-3-1555-2010, 2010.

Munro, R., Eisinger, M., Anderson, C., Callies, J., Corpaccioli, E., Lang, R., Lefebvre, A., Livschitz, Y., and Albinana, A. P.: GOME-2 on MetOp: From in-orbit verification to routine operations, in: Proceedings of EUMETSAT Meteorological Satellite Conference, Helsinki, Finland, 12-16 June 2006, p. 48, 2006.
Munro, R., Lang, R., Klaes, D., Poli, G., Retscher, C., Lindstrot, R., Huckle, R., Lacan, A., Grzegorski, M., Holdak, A., Kokhanovsky, A., Livschitz, J., and Eisinger, M.: The GOME2 instrument on the Metop series of satellites: instrument design, calibration, and level 1 data processing - an overview, Atmos. Meas. Tech. Discuss., 8, 8645-8700, doi:10.5194/amtd-8-86452015, 2015.

Rodgers, C. D. and Connor, B. J.: Intercomparison of remote sounding instruments, J. Geophys. Res., 108, 4116, doi:10.1029/2002JD002299, 2003.

Sakazaki, T., Fujiwara, M., Mitsuda, C., Imai, K., Manago, N., Naito, Y., Nakamura, T., Akiyoshi, H., Kinnison, D., Sano, T., Suzuki, M., and Shiotani, M.: Diurnal ozone variations in the stratosphere revealed in observations from the Superconducting Submillimeter-Wave Limb-Emission Sounder (SMILES) on board the International Space Station (ISS), J. Geophys. Res., 118, 2991-3006, doi:10.1002/jgrd.50220, 2013.

Sofieva, V. F., Rahpoe, N., Tamminen, J., Kyrölä, E., Kalakoski, N., Weber, M., Rozanov, A., von Savigny, C., Laeng, A., von Clarmann, T., Stiller, G., Lossow, S., Degenstein, D., Bourassa, A., Adams, C., Roth, C., Lloyd, N., Bernath, P., Hargreaves, R. J., Urban, J., Murtagh, D., Hauchecorne, A., Dalaudier, F., van Roozendael, M., Kalb, N., and Zehner, C.: Harmonized dataset of ozone profiles from satellite limb and occultation measurements, Earth Syst. Sci. Data, 5, 349-363, doi:10.5194/essd-5-349-2013, 2013.

Sofieva, V. F., Tamminen, J., Kyrölä, E., Laeng, A., von Clarmann, T., Dalaudier, F., Hauchecorne, A., Bertaux, J.-L., Barrot, G., Blanot, L., Fussen, D., and Vanhellemont, F.: Validation of GOMOS ozone precision estimates in the stratosphere, Atmos. Meas. Tech., 7, 2147-2158, doi:10.5194/amt-7-2147-2014, 2014.

Studer, S., Hocke, K., Schanz, A., Schmidt, H., and Kämpfer, N.: A climatology of the diurnal variations in stratospheric and mesospheric ozone over Bern, Switzerland, Atmos. Chem. Phys., 14, 5905-5919, doi:10.5194/acp-14-5905-2014, 2014.

Tamminen, J., Kyrölä, E., Sofieva, V. F., Laine, M., Bertaux, J.-L., Hauchecorne, A., Dalaudier, F., Fussen, D., Vanhellemont, F., Fanton-d'Andon, O., Barrot, G., Mangin, A., Guirlet, M., Blanot, L., Fehr, T., Saavedra de Miguel, L., and Fraisse, R.: GOMOS data characterisation and error estimation, Atmos. Chem. Phys., 10, 9505-9519, doi:10.5194/acp-10-9505-2010, 2010.

Tuinder, O.: O3M SAF Product User Manual, NRT and Offline Vertical Ozone Profile and Tropospheric Ozone Column Products, available at: http://o3msaf.fmi.fi/docs/pum/Product_User_ Manual_NOP_NHP_OOP_OHP_O3Tropo_Jul_2015.pdf (last access: 25 January 2016), 2015.

Tukiainen, S., Hassinen, S., Seppälä, A., Auvinen, H., Kyrölä, E., Tamminen, J., Haley, C. S., Lloyd, N., and Verronen, P. T.: Description and validation of a limb scatter retrieval method for Odin/OSIRIS, J. Geophys. Res., 113, D04308, doi:10.1029/2007JD008591, 2008.

Tukiainen, S., Kyrölä, E., Tamminen, J., Kujanpää, J., and Blanot, L.: GOMOS bright limb ozone data set, Atmos. Meas. Tech., 8, 3107-3115, doi:10.5194/amt-8-3107-2015, 2015.

van Gijsel, J. A. E., Swart, D. P. J., Baray, J.-L., Bencherif, H., Claude, H., Fehr, T., Godin-Beekmann, S., Hansen, G. H., Keckhut, P., Leblanc, T., McDermid, I. S., Meijer, Y. J., Nakane, H., Quel, E. J., Stebel, K., Steinbrecht, W., Strawbridge, K. 
B., Tatarov, B. I., and Wolfram, E. A.: GOMOS ozone profile validation using ground-based and balloon sonde measurements, Atmos. Chem. Phys., 10, 10473-10488, doi:10.5194/acp10-10473-2010, 2010.

van Oss, R., de Haan, J., Tuinder, O., and Delcloo, A.: O3M SAF Algorithm Theoretical Basis Document, NRT and Offline Vertical Ozone Profile and Tropospheric Ozone Column Products, available at: http://o3msaf.fmi.fi/docs/atbd/ Algorithm_Theoretical_Basis_Document_NOP_NHP_OOP_ OHP_O3Tropo_Jul_2015.pdf (last access: 25 January 2016), 2015.

van Oss, R. F. and Spurr, R. J. D.: Fast and accurate 4 and 6 stream linearized discrete ordinate radiative transfer models for ozone profile retrieval, J. Quant. Spectrosc. Ra., 75, 177-220, 2002.

van Peet, J. C. A., van der A, R. J., Tuinder, O. N. E., Wolfram, E., Salvador, J., Levelt, P. F., and Kelder, H. M.: Ozone ProfilE Retrieval Algorithm (OPERA) for nadir-looking satellite instruments in the UV-VIS, Atmos. Meas. Tech., 7, 859-876, doi:10.5194/amt-7-859-2014, 2014.
Waters, J. W., Froidevaux, L., Harwood, R. S., Jarnot, R. F., Pickett, H. M., Read, W. G., Siegel, P. H., Cofield, R. E., Filipiak, M. J., Flower, D. A., Holden, J. R., Lau, G. K., Livesey, N. J., Manney, G. L., Pumphrey, H. C., Santee, M. L., Wu, D. L., Cuddy, D. T., Lay, R. R., Loo, M. S., Perun, V. S., Schwartz, M. J., Stek, P. C., Thurstans, R. P., Boyles, M. A., Chandra, K. M., Chavez, M. C., Chen, G.-S., Chudasama, B. V., Dodge, R., Fuller, R. A., Girard, M. A., Jiang, J. H., Jiang, Y., Knosp, B. W., LaBelle, R. C., Lam, J. C., Lee, K. A., Miller, D., Oswald, J. E., Patel, N. C., Pukala, D. M., Quintero, O., Scaff, D. M., Van Snyder, W., Tope, M. C., Wagner, P. A., and Walch, M. J.: The Earth Observing System Microwave Limb Sounder (EOS MLS) on the Aura Satellite, IEEE T. Geosci. Remote, 44, 1075-1092, doi:10.1109/TGRS.2006.873771, 2006. 